\title{
Facing interfaces
}

\section{A clustering approach to grammaticalization and related changes}

\author{
Muriel Norde \& Karin Beijering \\ Humboldt University of Berlin/University of Antwerp
}

It has long been recognized that many instances of change that have been discussed within the framework of grammaticalization studies notoriously defy categorization, for instance because they share properties of grammaticalization and lexicalization (Brinton \& Traugott 2005), or because they share some properties of grammaticalization, but not all of them, as in the case of discourse markers (e.g. Ocampo 2006). In order to avoid these classification issues, we will argue that it is more useful to reduce grammaticalization and related changes to their "main mechanisms" (formal reanalysis and semantic reinterpretation), "primitive changes" (micro-changes on the levels of phonology, morphology, syntax, semantics and/or discourse), and "side effects" (e.g. obligatorification or layering). In grammaticalization and related changes, formal reanalysis and semantic reinterpretation tend to coincide with different sets of primitive changes. Primitive changes will be defined as ternary parameters with the values reduction, expansion, or zero, and it will be seen that they tend to cluster in different ways. Some of these clusters may coincide with changes traditionally labeled "grammaticalization", "degrammaticalization", or "lexicalization", but changes may also cluster in alternative ways. This novel approach to composite changes we term the "clustering approach", and we aim to show that this model of analysis allows for a more fine-grained account of composite changes than definition-based taxonomies.

Keywords: grammaticalization, izations, interfaces, composite and primitive changes 


\section{Introduction}

\subsection{Preamble}

In his book Histoire de la folie à l'âge classique (1972, discussed in Gutting 2005), the French philosopher Michel Foucault describes how in seventeenth- and eighteenth-century Western Europe, people suffering from mental illness came to be placed in special houses of internment, not for medical treatment, but with the intention to exclude them from society. In those times, the mad were not considered ill, but they formed part of a much larger category, which Foucault terms déraison. They were thus confined along with other people belonging to that category, such as prostitutes, vagabonds, or unemployed. Foucault's conclusions about the prevalent ethics of that time (which do not concern us here) have been contested (Gutting 2005), but his point that people were being grouped together on the basis of a criterion, idleness, which may strike us as absurd, nicely illustrates just how arbitrary taxonomies may be. Foucault's argument was cited in a paper by Gould \& Vrba (1982)1 to illustrate their claim that " $[t]$ axonomies are not neutral or arbitrary hat-racks for a set of unvarying concepts; they reflect (or even create) different theories about the structure of the world" (Gould \& Vrba 1982: 4). This, we will argue, is precisely the problem with previous attempts to classify changes as "grammaticalization", "lexicalization", "pragmaticalization" and so on. When such classifications are based on definitions which, as we will show in Section 1.2, vary from author to author, we do not get any closer to understanding the changes discussed in this article.

The study of grammaticalization and related phenomena has been a flourishing branch of historical linguistics since interest has been revived in the last decades of the twentieth century. However, this publication boom has also had its downside, which is that the notion of grammaticalization has become bleached and vague. This is evidenced not only by the variety of definitions discussed in the next two sections, but also by the sheer number of changes that have been labeled "grammaticalization" and which, at a first glance, appear to have little in common. To quote just a few examples from the first chapter in Hopper \& Traugott's introductory textbook on grammaticalization (2003), it is not immediately obvi-

${ }^{1}$ Gould \& Vrba (1982) coined the term "exaptation", a term that has later been introduced to historical linguistics by Lass (1990). 
ous what such changes as the rise of the Romance inflectional future, the adhortative and condescending usage of English let's, West African complementizers, or substandard French $i$ and elle as agreement markers have in common. Researchers have thus felt forced to introduce new terms, such as "primary" and "secondary" grammaticalization, or "pragmaticalization" to distinguish between different subtypes. As a result, classification issues have been on the grammaticalization agenda for decades and probably will be for some time to come.

Therefore, instead of using (canonical) definitions and (implicit or explicit) assumptions about directional preferences, we will put forward an analytic model in which we distinguish between three levels of observation: "mechanisms", "primitive changes", and "side effects". We will argue that reducing complex changes, such as the changes traditionally labeled "grammaticalization", to clusters of micro-changes at these levels may well offer a more diffuse account - not one indeed that is as well-ordered as previous approaches may appear - but one that is descriptively more adequate while still allowing for (statistical) generalizations on prototypicality. For although we agree with Newmeyer (1998: 235) that grammaticalization is an epiphenomenal phenomenon resulting from other changes, we do not agree with him that these changes are completely independent from one another. We are, of course, well aware that the observation that grammaticalization can be decomposed into primitive changes has been part and parcel of many earlier (critical) accounts of grammaticalization. However, what we see as the novelty of our approach is the systematic identification of clusters for each individual token of change.

Before we introduce our model, however, we will first discuss and compare some canonical definitions of grammaticalization and other complex phenomena in Sections 1.2 and 1.3. In the remaining subsections of Section 1, we will provide some background discussion of the difference between composite and primitive changes (Section 1.4), and of parametric analysis (Section 1.5). In Section 2, we aim to show that it is not possible to merely classify all instances of change as clear-cut instances of grammaticalization or of other types of language change (e.g. lexicalization, degrammaticalization, or pragmaticalization), because some of these instances have properties of more than one type of language change. We term these overlaps interfaces, and we will briefly illustrate some of them. In Section 3, we introduce our own approach and the three components it entails: main mechanisms (formal reanalysis and semantic reinterpreta- 
tion) in Section 3.1, primitive changes (i.e. micro-changes at the levels of syntax, morphology, phonology, semantics, and discourse) in Section 3.2, and changes we consider side effects, such as layering or persistence, in Section 3.3. Examples of this three-level analysis are given in Section 4. In Section 5, we conclude the article and offer suggestions for future research.

\subsection{Definitions of grammaticalization}

We will start with a discussion of some canonical definitions of grammaticalization and explain why we think that classifying instances of language change according to predefined labels or strict taxonomies is problematic. Most linguists would agree that the basic idea in grammaticalization studies is that grammatical elements originate in lexical items, which is reflected in Meillet's (1958 [1912]: 131) famous and often-cited definition, as quoted in (1).

(1) the attribution of a grammatical character to a previously autonomous word $^{2}$

However, upon closer inspection, this definition may not be as straightforward as it seems, as the adjective autonomous can be interpreted in different ways. Formally, "an autonomous word" may refer to a so-called free morpheme, that is, a morpheme that can stand on its own (e.g. a noun such as $d o g$ ), as opposed to a "bound morpheme" that is part of a larger linguistic unit (e.g. an affix such as -ly). Semantically, on the other hand, it may denote a morpheme with referential meaning, that is, a morpheme that has meaning of its own (e.g. a noun such as chair), as opposed to morphemes with relational or indexical meaning whose meaning has to be interpreted in context (e.g. the pronoun he). The term "grammatical character" is not further defined but is generally understood as "grammatical function" or "grammatical meaning".

Not only lexical items, but also grammatical(ized) elements may be subject to (further) grammaticalization, as stated in Kuryłowicz's (1975 [1965]: 52) classical definition of grammaticalization in (2):

(2) Grammaticalization consists in the increase of the range of a morpheme advancing from a lexical to a grammatical or from a grammatical to a

${ }^{2}$ Paul J. Hopper's (1991: 131) translation of Meillet's "l'attribution du caractère grammaticale à un mot jadis autonome". 
more grammatical status, e.g. from a derivative formant to an inflectional one.

Following this definition, grammaticalization is either a shift from lexical to grammatical status, or a shift from grammatical to even more grammatical status. While Kuryłowicz's definition is thus a bit more specific than Meillet's, it is still problematic, as it remains unclear how one is to assess "more grammatical status", that is, on what grounds some grammatical expressions may be considered to be "more grammatical" than others.

In some works, a distinction is made between the different types of change identified in Kuryłowicz's definition. The shift from lexical to grammatical status has been termed "primary grammaticalization", whereas the shift from grammatical to even more grammatical status is called "secondary grammaticalization” (Traugott 2002: 26; see Norde 2012a: 75-76 for discussion). The distinction between primary and secondary grammaticalization is also implicit in Hopper \& Traugott's (2003: 18) definition of grammaticalization in (3).

(3) the change whereby lexical items and constructions come in certain linguistic contexts to serve grammatical functions and, once grammaticalized, continue to develop new grammatical functions

According to Detges \& Waltereit (2002: 188) however, only the first part of Hopper \& Traugott's definition - primary grammaticalization - counts as grammaticalization proper. Increasing grammaticalization, as denoted by the second part of the definition (i.e. secondary grammaticalization), is considered to be a subsequent stage involving increasing bondedness or morphologization, for example, cliticization and affixation (see further Norde 2009: 20-21).

What these definitions, and many others, have in common, is that they focus primarily on input and output categories, which are "lexical" and "grammatical" respectively. However, these characterizations remain rather vague as to how grammatical meaning or status is formally expressed. The following quotes by Heine \& Reh in (4), and Fischer \& Rosenbach in (5), are more specific about the micro-changes involved in grammaticalization.

(4) With the term 'grammaticalization' we refer essentiality to an evolution whereby linguistic units lose in semantic complexity, pragmatic significance, syntactic freedom, and phonetic substance, respectively. (Heine \& Reh 1984: 15) 
(5) Grammaticalization is generally seen as a process whereby a lexical item, with full referential meaning (i.e. an open-class element), develops grammatical meaning (i.e. it becomes a closed-class element); this is accompanied by a reduction in or loss of phonetic substance, loss of syntactic independence and of lexical (referential) meaning. (Fischer \& Rosenbach 2000: 2)

The problem with these definitions is that they can be taken to mean that all micro-changes mentioned need to occur in order for a change to qualify as grammaticalization. However, this is often not the case. For example, a shift from present participle to conjunction (seeing) or preposition (regarding) does involve loss of referential meaning, but not of phonetic substance. On a strict interpretation of the definitions in (4) and (5), then, these changes would not be valid examples of grammaticalization, even though it is generally assumed that they are (see e.g. Brinton \& Traugott 2005: 117-122). Boye \& Harder (2012) therefore argue that grammatical expressions and grammaticalization cannot be defined in terms of specific phonological, morphosyntactic, or semantic features, alone or in combination, but that these notions "can be defined in terms of the ancillary status that grammatical expressions by linguistic convention have in relation to other expressions." (2012: 7). The concept of "ancillary status" signifies that grammatical expressions (morphemes, words, constructions), in contrast to lexical expressions that may (or may not) convey the main point of a linguistic message, are conventionally specified as non-carriers of the main point, serving instead an ancillary communicative purpose as secondary background elements (2012: 6). In Boye \& Harder's view, they are "discursively secondary", which means that they carry "lower (discourse) prominence than one or more syntagmatically related expressions in the utterance" (2012: 8).

So far, a couple of traditional and more recent definitions have been discussed. However, as noted by Narrog \& Heine (2011) in The Oxford Handbook of Grammaticalization, which presents the state of the art in research on grammaticalization, there is still no generally accepted definition of grammaticalization:

(6) Going through the chapters of this volume, the reader will notice that grammaticalization is far from being a uniform concept, and various definitions have been proposed. [. . .] Still, when controversies arise many scholars agree in draw attention [sic.] to the classic definition by Kuryłowicz to help settle the issue of what should be subsumed under the rubric of grammaticalization. (Narrog \& Heine 2011: 2-3) 
All in all, it seems impossible to come up with a generally accepted definition of grammaticalization. Notions of grammaticalization, as they are currently defined in the literature, seem to be too diverse, which makes grammaticalization a heterogeneous concept that captures widely diverging developments. Since there is no consensus on a definition, one might wonder whether an instance of "grammaticalization" in view A would also qualify as an instance of "grammaticalization" from perspective B.

Moreover, in the literature there is a tendency to pick out a subset of properties, on the basis of which one attributes the label "grammaticalization" to a particular change. For example, reported instances of grammaticalization are hardly ever characterized by all characteristics (such as Lehmann's 1995 [1982] "parameters" or Hopper's 1991 "principles") of grammaticalization. Instead, an arbitrary subset of features is generally considered to be sufficient to call a change an instance of grammaticalization. Not only do predefined lists of properties run the risk of being circular (e.g. grammaticalization has the properties A, B, and C; hence, property $\mathrm{A}+\mathrm{B}+\mathrm{C}$ is a case of grammaticalization), they may also lead to misconceptions and mismatches.

Another complicating factor in determining the key defining properties of grammaticalization is the fact that not all grammatical items share the same properties. Modal auxiliaries and inflections are both grammatical elements, but they differ in properties such as subjectification and bonding. As a result, it seems impossible to characterize changes uniquely as an instance of grammaticalization, since individual cases may show varation in primitive changes and side effects.

For the reasons given above, we propose to abandon the idea that all linguistic changes can be classified in terms of predefined categories such as "grammaticalization". We will therefore refrain from formulating yet another definition of grammaticalization, but focus on clusters of microchanges in grammaticalization, and the characteristics that it shares with other types of language change.

\subsection{Other "izations"}

Along with the interest in grammaticalization phenomena, a variety of new terms related to linguistic change, likewise ending in ization, emerged in the field of grammaticalization studies, such as lexicalization, degrammaticalization, and pragmaticalization. Since these concepts are, more 
often than not, discussed in relation to grammaticalization, they suffer from the same definitional confusion. In this article, we will use "ization" as a cover term for all these phenomena, which have in common that they are composite types of language change, as opposed to changes involving a single linguistic level only, e.g. morphologization, subjectification, or semanticization. We will argue that the izations apply at different domains of language (lexicon, grammar, discourse). Because of this, the concepts of lexicalization and pragmaticalization are useful to delineate and distinguish grammaticalization from other types of language change. Canonical definitions of the other izations are given in the remainder of this section.

One of the most cited definitions of lexicalization is the one provided by Brinton \& Traugott (2005: 96):

(7) Lexicalization is the change whereby in certain linguistic contexts speakers use a syntactic construction or word formation as a new contentful form with formal and semantic properties that are not completely derivable or predictable from the constituents of the construction or the word formation pattern. Over time there may be further loss of internal constituency and the item may become more lexical.

In this definition, lexicalization is restricted to processes of fusion, the input of which may be phrases, as in dyed in the wool, or single lexemes that arose out of a fusion of two or more words, as in lord (< Old English hlaf weard 'loaf guardian'). Other authors, however (e.g. Norde 2009: 9-11), use a wider definition of lexicalization, that is, one that includes non-productive processes of word formation (e.g. ellipsis: pub < public house, or coinage: hobbit), and "clippings", where part of a word (often a derivational affix) comes to be used as an independent lexeme (e.g. ism as a hypernym for all ideologies ending in ism). In the present study, lexicalization includes both these subtypes, lexicalization as fusion, that is, various kinds of univerbations resulting in morphologically and semantically opaque linguistic items, and lexicalization as separation: clippings of bound morphemes resulting in (semi-)independent words. Regular processes of word formation which are largely transparent, such as compounding, derivation, or conversion will not be considered lexicalization.

Whether or not the rise of discourse markers can be considered a separate ization - pragmaticalization - has been the subject of much debate (see Beijering 2012: 56-60). We will return to this issue in Section 2.3, but to illustrate the main properties of this type of change we cite Dostie's (2009: 203) definition in (8): 
(8) The term [pragmaticalization] refers to a process of linguistic change in which a full lexical item [...] or grammatical item [. . . changes category and status and becomes a pragmatic item, that is, an item which is not fully integrated into the syntactic structure of the utterance and which has a textual or interpersonal meaning.

The final set of izations that need to be mentioned at this point are the three subtypes of degrammaticalization. Norde (2009) provides one general definition, quoted in (9), plus three for each subtype of degrammaticalization, quoted in (10)-(12).

(9) Degrammaticalization is a composite change whereby a gram in a specific context gains in autonomy or substance on more than one linguistic level (semantics, morphology, syntax, or phonology). (Norde 2009: 120)

(10) Degrammation is a composite change whereby a function word in a specific linguistic context is reanalyzed as a member of a major word class, acquiring the morphosyntactic properties which are typical of that word class, and gaining in semantic substance. (Norde 2009: 135)

(11) Deinflectionalization is a composite change whereby an inflectional affix in a specific linguistic context gains a new function, while shifting to a less bound morpheme type. (Norde 2009: 152)

(12) Debonding is a composite change whereby a bound morpheme in a specific linguistic context becomes a free morpheme. (Norde 2009: 186)

In Section 4 we provide examples about which most researchers agree that they represent a specific type of ization, with the aim of illustrating how mechanisms, primitive changes, and side effects may cluster in various types of change.

\subsection{On composite and primitive changes}

What makes izations such a fascinating object of study is that they involve changes on several linguistic levels: phonology, morphology, syntax, semantics, pragmatics, and discourse. Not all levels need be affected, and they need not be affected simultaneously, but this multi-dimensionality clearly sets izations apart from changes on one level only, such as lenition (phonological) or pejoration (semantic). We will therefore term izations "composite changes", consisting of basic mechanisms of change, several "primitive changes", and their concomitants. We will argue that mechan- 
isms, primitive changes, and side effects are not themselves specific to one particular ization, but the way in which they cluster differs for each ization, and some of these clusters can be identified as a "prototypical" instance of a given ization. However it will also be seen that there are clusters which are hybrid cases at the interface of these prototypes.

The advantage of analyzing composite changes in terms of primitive changes is that primitive changes are far less controversial, for two reasons. First, they only pertain to a single linguistic level, not to several levels simultaneously (as do izations). Secondly, they are parametric, meaning (in the case of primitive changes) that a linguistic property may undergo reduction, expansion, or neither, and which of these three possibilities is at stake is usually quite straightforward to make out. For example, no one would contest the view that the loss of inflections or segments involves reduction, not expansion, on the morphological and the phonological level respectively. Conversely, the acquisition of referential meaning or an increase in the number of syntactic slots in which a given item may appear are unequivocal instances of expansion on the levels of semantics and syntax. The concept of "parameter" will be discussed in more detail in the next section.

\subsection{On parameters}

In linguistics, the term "parameter" has been used to refer to different concepts, so it needs to be explained how we apply it in our approach. The term is well known from Chomskyan linguistics (see Chomsky's Principles and Parameters theory), in which parameters are binary switches that determine variability between languages. For example, the so-called Pro-Drop Parameter may be switched on, in which case pronouns can be omitted (most often in subject position), or switched off, in which case pronouns have to be overtly expressed. When we use the term "parameter", however, we do not use it in the Chomskyan sense but refer to its application in diachronic linguistics, most prominently in Lehmann's seminal study on grammaticalization (1995 [1982]). Lehmann's "parameters of grammaticalization" pertain to three principal aspects of the autonomy of a linguistic sign, that is, weight, cohesion, and variability, which can be analyzed paradigmatically and syntagmatically. The resulting six parameters are given in Table 1.

Unlike the Chomskyan parameters, Lehmann's parameters can be assigned three values: reduction, expansion, or neither. Each parameter 
Table 1. Lehmann's parameters (Lehmann 1995 [1982]: 123)

\begin{tabular}{lll}
\hline & Paradigmatic & Syntagmatic \\
\hline Weight & Integrity & Structural scope \\
Cohesion & Paradigmaticity & Bondedness \\
Variability & Paradigmatic variability & Syntagmatic variability \\
\hline
\end{tabular}

is associated with one or more primitive changes. For example, the parameter of integrity applies to semantic and phonological substance, and to morphosyntactic properties. In grammaticalization, we would expect reduction on all three levels (change from referential to grammatical content, reduction or loss of phonemes, or loss of inflections), whereas in degrammaticalization, we would expect expansion (Norde 2009: 130-132; Trousdale \& Norde 2013: 43). This expectation is not always borne out, however, as one or more parameter(s) may remain "inactivated". Integrity on the phonological level, for example, often remains unaltered. In other words, phonological substance need not be reduced in grammaticalization (this is especially true of primary grammaticalization), nor does it necessarily increase in degrammaticalization. For this reason, we will argue that it is often difficult to classify izations on the basis of these parameters alone. What, for instance, would count as a valid instance of grammaticalization? Do all parameters have to involve reduction? And if not, is there a minimum of primitive changes that have to occur, or are some primitive changes more decisive than others?

\section{Interfaces}

Like "parameter", the term "interface" can be interpreted in different ways. In this article, we use it to denote overlap areas between different izations. It should not be confused with the generative use of this notion where "interface" relates to "interface rules" and the "Interface Level", that is, the mapping of different modules of grammar at the Interface Level, commonly known as Logical Form (see Adger 2003: 31-32, 145).

We suggest that the synchronic concepts of grammar, lexicon, and discourse overlap to some extent, as do the various izations. In other words, interfaces can both be synchronic and diachronic. Figure 1 illustrates the functional-typological approach to language (e.g. Brinton \& Traugott 


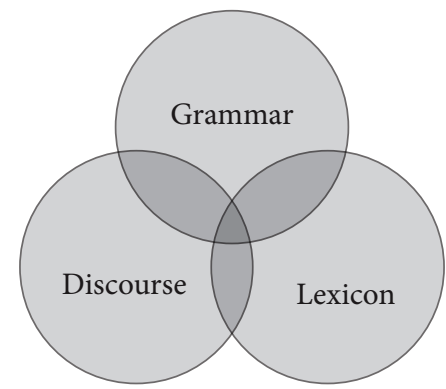

Figure 1. Synchronic interfaces

2005), according to which "grammar", "discourse", and "lexicon" are not separate modules, but gradient categories, which overlap precisely because items and constructions may, in the course of time, be transferred from one domain to the other.

With "diachronic interface" (Figure $2^{3}$ ), we refer to the observation that izations may have some properties in common, e.g. bleaching or univerbation. This makes strict classifications difficult, if not impossible, because it raises the problem of which primitive changes can be argued to be the defining properties of a given ization. Examples of such interface changes will be given in Sections 2.1-2.3. Ultimately, we aim to overcome the problematic status of such "hybrid cases" by means of the clustering approach proposed further on in this article.

\subsection{The grammaticalization-lexicalization interface}

Following mainstream thinking in grammaticalization studies that change is gradual, we argue that grammar and lexicon should not be seen as two

\footnotetext{
3 The intersection between grammaticalization and degrammaticalization in Figure 2 may seem strange at first, as these could be argued to be changes in the opposite direction, but there are two reasons for this overlap. First, some primitive changes, e.g. subjectification (Norde 2011), may occur in both grammaticalization and degrammaticalization. Secondly, some changes have been characterized as grammaticalization by some, but degrammaticalization by others. For instance, Askedal (2003: 29) considers the history of the Swedish $s$-genitive as an example of increasing grammaticalization (contra Norde 1997 who argues it is degrammaticalization) because the $(s-)$ genitive comes to be restricted to attributive contexts, whereas genitives governed by verbs or prepositions are lost. In his view, loss of constructional contexts is indicative of grammaticalization, whereas Norde (2009: 177-178) adopts the view that (de)grammaticalization is a construction-specific change on which the loss of other constructions involving the same item has no bearing.
} 


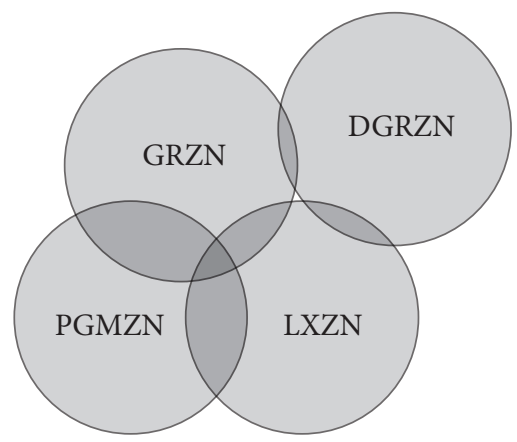

Figure 2. Diachronic interfaces (GRZN = grammaticalization; DGRZN = degrammaticalization; LXZN = lexicalization; PGMZN = pragmaticalization)

distinct modules, but as gradient entities (see Figure 1). For example, when a present participle grammaticalizes into a preposition or a conjunction (Brinton \& Traugott 2005: 117-122), this is not an abrupt change, but one encompassing a series of contiguous steps. This gradualness is reflected by so-called "bridging contexts" (Heine 2002), which are ambiguous with respect to an old and a new function. An example of such a bridging context is provided in (13), where following can be either adjectival ('the day which followed his intervention') or prepositional ('the day after his intervention').

(13) the day following his intervention

The gradient nature of both grammar and lexicon as seen by Brinton \& Traugott (2005) is illustrated in Figures 3 and 4. On this continuum, Brinton \& Traugott identify six cluster points, three lexical and three grammatical, which are exemplified in (14) and (15) respectively.

(14) L1: partially fixed phrases (lose sight of)

L2: complex semi-idiosyncratic forms (unhappy, desktop)

L3: simplexes and unanalysable idiosyncratic forms (desk, over-the-hill)

(15) G1: periphrases (be going to)

G2: semi-bound forms, such as function words and clitics (must, 'll)

G3: affixes (both inflectional and derivational) ${ }^{4}$

\footnotetext{
${ }^{4}$ Note that G1-G3 are "levels of grammaticality with respect to degrees of fusion with external elements" (Brinton \& Traugott 2005: 93). Increasing grammaticality is primarily associated with increasing bondedness, as in Hopper \& Traugott's (2003: 7) cline of grammaticality.
} 


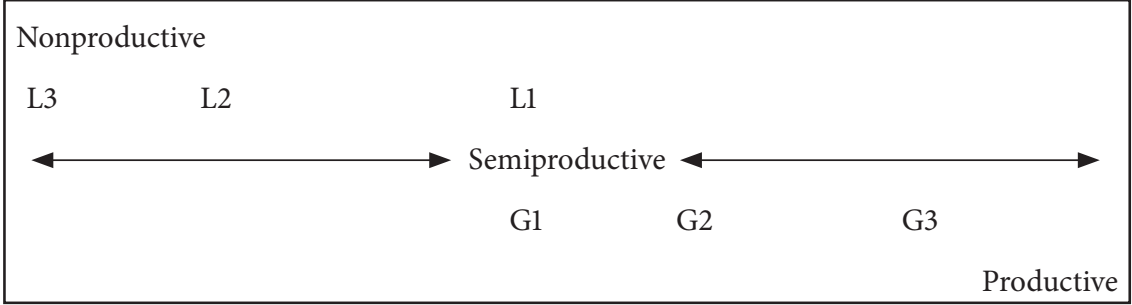

Figure 3. Synchronic clines of lexicality and grammaticality (Brinton \& Traugott 2005: 94)

Figure 3 is a synchronic cline, in which the double-sided arrows indicate that the different levels form a continuum, ranging from nonproductive via semiproductive to productive. ${ }^{5}$

Figure 4 is a diachronic cline, in which the two-sided arrows have been replaced by unidirectional arrows, as changes usually proceed in one direction, that is, toward the L3 pole or the G3 pole; note, however, that changes need not go to the very end-point in either direction. As Brinton \& Traugott (2005: 101) put it: "As speakers adapt units, they will not necessarily move them all the way down the cline; that is, not all units will 'come to completion' at the stage of L3 or G3."

Examples of linguistic items at the lexicalization-grammaticalization interface are temporal adverbs such as today (< Old English to doege at day. DAT'). In general, it is very hard to unequivocally assign lexical or grammatical status to adverbs because the notion of "adverb" comprises subsets of lexical, grammatical, and "indeterminate" forms (forms that have partly concrete and partly abstract meaning). According to Fischer (2007), today is a clear case of lexicalization. Meillet (1958 [1912]: 138-139), on the other hand, classifies German heute 'today' as a prototypical instance of grammaticalization, whereas Brinton \& Traugott (2005: 63) note that today qualifies as one of "the most frequently cited problematic examples" of phrases that have become simplexes.

The today example may serve to show just why grammaticalization and lexicalization cannot always be easily distinguished: they have some properties in common, most notably fusion, coalescence, and demotivation (see Brinton \& Traugott 2005: 110 for a list of differences and similarities

5 In Brinton \& Traugott (2005), productivity is understood as the ability to form new expressions. On this view, specific items such as simplexes are nonproductive, whereas items which always combine with others are maximally productive. 


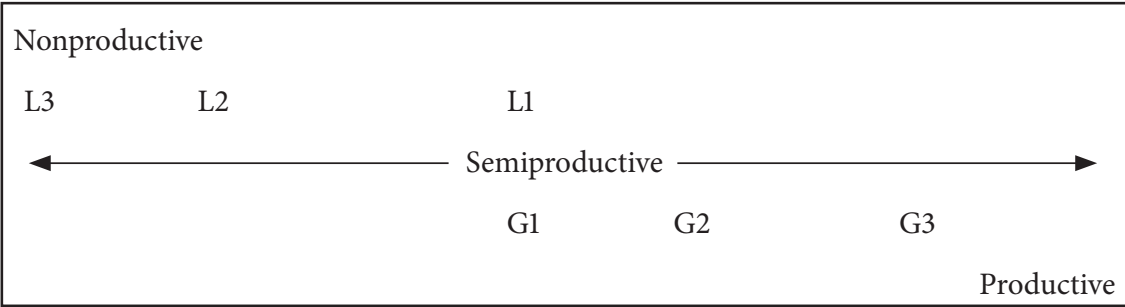

Figure 4. Gradualness: Diachronic change along clines of lexicality and grammaticality (Brinton \& Traugott 2005: 102)

between grammaticalization and lexicalization). The reason why lexicalization and grammaticalization share these characteristics, as Himmelmann (2004: 36) correctly observes, is that the input of each process is "the spontaneous and productive combination of lexical items in discourse". They differ, however, in the subsequent steps: where lexicalization involves univerbation or fossilization of specific phrases, grammaticalization involves the collocation of one specific element with a class of other elements, resulting in the expansion of possible syntagmatic contexts. Fischer (2008: 352) goes one step further when she suggests that a change which only affects a particular token (e.g. Old English $p a$ hwile be 'that time that' > Modern English while) is in fact "much closer to lexicalization than to grammaticalization". Lehmann (2004: 169) takes the slightly different view that lexicalization and grammaticalization are successive steps in a given change. On this view, univerbation of pa hwile pe would be lexicalization, whereas the loss of referential meaning and morphosyntactic properties is grammaticalization. The problem with viewing lexicalization and grammaticalization as processes in a temporal sequence is, however, that it is not always clear from the literature whether univerbation or fossilization indeed precedes the acquisition of more grammatical properties. It is not inconceivable that primitive changes occur more or less simultaneously and feed one another.

Summing up thus far, since grammaticalization and lexicalization may both have increasingly fixed collocations as their input, and share some primitive changes, the issue of classifying a given composite change as either grammaticalization or lexicalization is heavily dependent on one's definitions. Moreover, if the only changes involved are the primitive changes that are found in both (as is the case with today type adverbs) classification is just not possible. 


\subsection{The lexicalization-degrammaticalization interface}

"Degrammaticalization", as its prefix suggests, is a type of change that runs counter to grammaticalization, in that the primitive changes typically associated with grammaticalization (e.g. semantic bleaching, phonological reduction) find their opposites in degrammaticalization (e.g. semantic and phonological strengthening). It is important to keep in mind, however, that degrammaticalization is not simply the mirror image of grammaticalization, because apart from some crucial differences, some similarities may be observed as well (Norde 2011: 476-477):

(i) Both grammaticalization and degrammaticalization are gradual, in the sense that they comprise a series of small changes (i.e. it is not necessarily the case that all primitive changes occur simultaneously).

(ii) Both result in novel grams or structures. Thus, in cases where grams can be shown to continue a less grammatical function that had always been around, however marginalized, the change will not qualify as a case of degrammaticalization.

(iii) Both are context-internal changes, in the sense that "the identity of the construction and the element's place within it are always preserved" (Haspelmath 1999: 1064). The (de)grammaticalization gram changes in function, but there is no change to the surface structure of the construction in which the gram appears, at least not initially.

Apart from the directionality of the primitive changes involved, the most significant difference between grammaticalization and degrammaticalization is that the latter does not form chains (Norde 2009: 123). For instance, it is not possible for a future suffix (e.g. ai in chanterai) to develop into a full verb meaning 'to possess'. Such mirror-image developments involving several stages are indeed not attested, in other words, there are no degrammaticalization "chains" of changes.

Because its direction is opposite to grammaticalization, degrammaticalization is similar to lexicalization, which likewise is a development away from the grammatical pole (see Figure 4). There are many instances of change that have been categorized as lexicalization as well as degrammaticalization, most notably the shift from function words and affixes to members of major word classes. Some examples of this rather productive process are given in (16) below. Pronouns can be used as nouns (16a) or as verbs (16b); a subjunction like if can be used as a noun (16c), a verb (16d), 
or as an adjective (16e). Another example is the suffix ism, which can be used as a noun (17).

(16) a. Please tell me all my she's are not he's. ${ }^{6}$

b. Every time Heyton tells me that "we beat them off. . . this time,"

I can't help but think "whoa dude. I was here fighting these guys and you're saying you did what to them? Don't you 'we' me man - that was all you.' 7

c. Too many ifs cloud nuclear future. ${ }^{8}$

d. Stop "iffing" and start working on your to do list. ${ }^{9}$

e. Presenting gifts has gotten become rather iffy. ${ }^{10}$

(17) Paxton argues that fascism isn't really an "ism." "isms" are defined by a core set of principles, which in turn tend to drive policies. ${ }^{11}$

In Norde (2009), changes such as the above are distinguished from the degrammaticalization changes in (18) and (19). Example (18), from Middle Welsh (Willis 2007: 294, 297) illustrates the subtype of degrammation (see the definition in (10), whereby an adposition yn ol develops into a verb nôl 'to fetch'. Crucial in this development are bridging contexts such as (18a), where the string $y n$ ol is ambiguous between adposition and verb; example (18b) shows a later stage, when $y n$ ol has become monomorphemic and acquired full verbal inflections.

(18) a. Yna yd aeth y gweisson ynoly varcha'e arueui. then PART went the lads after his horse and his weapons 'Then the lads went after/went to fetch his horse and his weapons.'

b. Nolwch $y$ Brenini 'w examnio. fetch.2PL.IMP the King to 3MASC.SG examine.INF 'Fetch the king to be cross-examined.'

Example (19b), from Connemara Irish, is an instance of debonding (see the definition in (12)) of a verbal affix into a pronoun (Doyle 2002: 68).

\footnotetext{
${ }^{6}$ http://www.backyardchickens.com/t/339406/please-tell-me-all-my-shes-are-not-hes; accessed 16 Oct. 2014.

7 http://forums.ddo.com/showthread.php? $\mathrm{p}=4567242$; accessed 16 Oct. 2014.

${ }^{8} \mathrm{http} / / / w w w . t h e s t a r . c o m / o p i n i o n / 2009 / 06 / 15 /$ too_many_ifs_cloud_nuclear_future.html; accessed 16 Oct. 2014.

${ }^{9} \mathrm{http} / / / \mathrm{xsell}$ resources.com/index.php?option=com_content\&view=article\&id=70; accessed 16 Oct. 2014.

10 http://orange8957.tumblr.com/post/21638270518; accessed 16 Oct. 2014.

${ }^{11}$ http://gdaeman.blogspot.nl/2005_12_01_archive.html; accessed 16 Oct. 2014.
} 
(19) a. molfa-maid

Early Modern Irish

praise.FUT-1PL

b. molfaid muid

Contemporary Connemara Irish

praise.FUT we

'we will praise'

At first glance, the changes in (16) and (17) may seem of the same kind as those in (18) and (19). What sets (16) and (17) apart from (18) and (19), however, is that in the former set, the function words and affixes serve immediately as nouns, verbs, or adjectives, without having been subject to a development involving "bridging contexts" (see Section 2.1). The case of ism is an example of a non-productive formation of a new lexical item, and is therefore considered a lexicalization as separation (lexicalization II). Another difference is that in muid the meaning is still relational, whereas ism is an example of a shift from relational to referential meaning (see Table 4 in Section 4 ).

\subsection{Discourse markers and the grammaticalization-lexicaliza- tion-pragmaticalization interface}

Discourse markers form an intriguing linguistic category. Their development does not strictly conform to most standard definitions of grammaticalization. Nevertheless, several solutions have been proposed to include discourse markers in the domain of grammar, for example, by extending the definition of grammaticalization to the acquisition of discourse functions (as e.g. by Traugott 1997 and Diewald 2011), or by considering the rise of discourse markers as a special subtype of grammaticalization (e.g. Wischer's 2000 "grammaticalization II"). On the other hand, there is also overlap with lexicalization, as we will show.

In this section, we will argue that discourse markers form a category of their own. As such, their development can be viewed as an instance of pragmaticalization, a composite change in its own right (see Ocampo 2006, Norde 2009: 23). In a recent paper on discourse markers, Lewis (2011: 418-421) notes a number of issues relating to discourse markers on which there is no consensus. In particular, it is unclear whether discourse markers constitute a syntactic or a pragmatic category, which types of expressions should be included, how they relate to categories such as connectives, interjections, modal particles, speaker-oriented sentence adverbials, and, finally, whether or not the term "discourse marker" is synonymous with 
terms such as "discourse connective", "pragmatic marker" and "pragmatic particle". In this article, we will be using the term "discourse marker", adopting the relatively wide definition by Onodera (2011: 615): "A discourse marker signals the speaker's view/attitude/judgement with respect to the relationship between the chunks of discourse that precede and follow it [. . .]." In addition, we follow Heine (2013: 1209) in assuming the following basic characteristics of discourse makers:

(i) They are syntactically independent from their environment.

(ii) They are typically set off prosodically from the rest of the utterance.

(iii) Their meaning is non-restrictive.

(iv) Their meaning is procedural rather than conceptual-propositional.

(v) They are non-compositional and as a rule short.

As expected, lack of agreement on the status of discourse markers implies that there are diverging views on their development as well. Like many cases of grammaticalization and lexicalization, for instance, those discussed in the previous sections, they may develop out of fixed collocations, as well as involve fusion/fossilization, loss of referential content and morphosyntactic properties, and so on. On the other hand, the rise of discourse markers is crucially different from lexicalization and grammaticalization (Brinton \& Traugott 2005: 136-139), for instance because it involves scope increase instead of scope reduction, and an increase in syntactic freedom instead of syntactic fixation.

In view of the above, then, it is not surprising that several changes have been classified as grammaticalization, lexicalization, or pragmaticalization. Modal particles (e.g. German denn, Dutch ook, Norwegian nok) are prototypical examples of linguistic items at the grammaticalizationpragmaticalization interface. Their development has been claimed to be an instance of "grammaticization" (Abraham 1991), or grammaticalization accompanied by subjectification (Diewald 2011). Since modal particles are often included in the class of discourse markers (e.g. Aijmer \& SimonVandenbergen 2009), their development could also be a case of pragmaticalization (Aijmer 1997).

Items that share properties of lexicalization and pragmaticalization are various types of conversational routines, such as please, goodbye, and thanks. Blank (2001) and Aijmer (1997) classify conversational routines as lexicalized formulas. However, because of their communicative functions, conversational routines have features in common with discourse markers. 
The discourse marker I think is an example of a linguistic expression that has been assigned widely diverging statuses. The phrasal discourse marker I think has, because it is fixed and partially fused (Brinton \& Traugott 2005: 137), been claimed to be an instance of grammaticalization (Thompson \& Mulac 1991, Brinton 1996, Brinton \& Traugott 2005). It has been viewed as an instance of pragmaticalization as it "permits, for example, extensions of meaning involving the speaker's attitudes to the hearer or to the message" (Aijmer 1997: 3), and it has been conceived of as a case of lexicalization (Schiffrin 1987: 319, Fischer 2007). Fischer (2007: 112) concludes that "parenthetical phrases like I think etc. are best seen as formulaic tokens because they lose some referential content, being narrowed down to a more epistemic, evaluative meaning."

\section{The clustering approach: Preliminaries and definitions}

In this section, we will present our unified account of grammaticalization and other composite changes. For our analysis, we will be looking at the following levels:

(i) basic mechanisms of change: formal reanalysis and semantic reinterpretation

(ii) primitive changes: at the levels of phonology, morphology, syntax, semantics, and discourse

(iii) side effects: Hopper's (1991) "principles of grammaticalization", some of the properties of grammaticalization as suggested in Brinton \& Traugott (2005: 110), as well as some changes associated with some of Lehmann's parameters

In the next three sections, we will briefly outline the mechanisms, primitive changes, and side effects, which collectively form the basis of our clustering approach. We will then apply this approach to a set of (very different) izations in Section 4.

\subsection{Mechanisms}

The principal mechanisms involved in izations are formal reanalysis and semantic reinterpretation. In our approach, semantic and formal changes are considered to be equally important. As regards the formal changes, 
we agree with Hopper \& Traugott (2003) that reanalysis is an important mechanism in grammaticalization. ${ }^{12}$ Following Rosenkvist (2004), we distinguish three levels of reanalysis:

a. Hierarchical reanalysis: changes in hierarchical structure (e.g. scope increase in extra-sentential discourse markers); for instance, I think in He is not at home, I think

b. Categorical reanalysis: change of category label from one word class to another (e.g. from noun to preposition). In our approach, nouns, (main) verbs, and adjectives are major categories. Adverbs are hybrid: those with referential meaning (e.g. quickly) are considered a major category; those with relational or modifying meaning (e.g. very) a minor category. Other minor categories include pronouns and adpositions.

c. Constituent-internal reanalysis: changes in constituent structure and boundaries (e.g. in the development from [NP of NP] construction to complex preposition construction: [[back [of the barn] ] $>[[$ back of $][$ the barn]], or from compound to simplex: Old English [[hlaf][weard]] > Modern English [lord]

The different types of reanalysis may coincide. For example, constituentinternal reanalysis may (e.g. may be > maybe) but need not (lord) result in a change of category label. Likewise, a change in category label may be accompanied by hierarchical reanalysis, as is the case for adverbials that develop into discourse markers.

Semantic reinterpretation relates to referential and relational meaning. For example, when nouns lose referential meaning, they lose the ability to identify participants in discourse; when verbs grammaticalize, they lose the ability to report new events (Hopper 1991: 30). The basic processes underlying semantic reinterpretation are metaphorization and metonymization (Traugott \& Dasher 2001: 27-34). Metaphorization is defined as "an analogical principle [which] involves conceptualizing one element of a conceptual structure $\mathrm{C}_{\mathrm{a}}$ in terms of an element of another conceptual structure $\mathrm{C}_{\mathrm{b}}$ " (Traugott \& Dasher 2001: 28). Typical examples include the shift from body part nouns to spatial adpositions, as in Old Danish baker 'back' > Modern Danish bag 'behind', or English front (originally meaning 'fore-

${ }^{12}$ But see Haspelmath (1998) for a different view. We also acknowledge that reanalysis itself can be motivated by other factors, e.g. analogy with similar constructions that facilitate reinterpretation of surface structures (De Smet 2009). This issue is outside of the scope of the present article but is definitely one that requires further consideration (see Section 5). 
head') > in front of. Metonymization is the term used by Traugott \& Dasher to refer to "a conceptual mechanism by which invited inferences in the associative, continuous stream of speech/writing come to be semanticized over time" and in their view, it "provides as rich an explanation as metaphorization for semantic change, and in many cases a richer one" (2001: 29). Metonymization plays a crucial role in their "Invited Inferencing Theory of Semantic change", which is concerned with the semanticization of pragmatic meaning. The example of while cited in Section 2.1 is a change that involves metonymization, because the simultaneity of two events "invited" the inference of contrast, and thus the temporal connective developed into an adversative one (as in Some people love fish while others hate it).

For prototypical examples of izations (i.e. changes about which authors predominantly agree that they represent a specific type of ization), the categorical reanalysis and semantic reinterpretation involved are the following:

(i) Primary grammaticalization is a shift from a major to a minor category, as well as a shift from referential to relational meaning.

(ii) Secondary grammaticalization is a shift from a minor to a minor category, as well as a shift from relational to (other) relational meaning.

(iii) Lexicalization as fusion is a shift from major to major category, as well as a shift from referential to (other) referential meaning.

(iv) Lexicalization as separation does not involve a shift from one category to another, because here part of a word (an affix or a compound member) is clipped off. As regards semantic reinterpretation, the shift is from relational to referential, but of a particular kind, because the affix or compound member becomes a hypernym for all derived forms or compounds it occurs in.

(v) Degrammation is a shift from a minor to a major category, as well as a shift from relational to referential meaning.

(vi) Deinflectionalization is a shift from a minor to a minor category, as well as a shift from relational to (other) relational meaning.

(vii) Debonding is a shift from a minor to a minor category, as well as a shift from relational to (other) relational meaning.

(viii) Pragmaticalization is a shift from a major or a minor to a minor category, as well as a shift from referential or relational to communicative meaning.

However, while this categorization identifies features found in different izations, it is still too coarse, because it groups together changes that are 
really different, e.g. conversions (see Section 2.2) and degrammation, or deinflectionalization and debonding. Therefore, we will need to consider the primitive changes as well, but as we have seen in the previous section, there are no strict one-to-one correspondences between izations and (clusters of) primitive changes attested, so these will have to be scrutinized for each case individually. In addition, side effects such as layering and persistence need to be included in the analysis, because these can be used to distinguish between, for instance, lexicalization as separation and debonding.

\subsection{Primitive changes}

Primitive changes (see Section 1.4) are, in principle, independent of the type of ization, less controversial than ambiguous labels such as "grammaticalization", and independent of one's definition of "lexical" or "grammatical". They have three values: expansion, reduction, or zero (no change). In this section, we propose parameters for each linguistic level (adapted in part from Lehmann's 1995 [1982] parameters of grammaticalization), and we briefly introduce the primitive changes that form part of our model; more details on these changes in specific izations will be given in Section 4.

With respect to syntax there are two parameters: syntactic variability and syntactic autonomy. Syntactic variability denotes the flexibility of a linguistic item, that is, the number of syntactic slots that an element may occupy. For items developing, for instance, into an adverb or discourse marker, there is an increase in syntactic variability, whereas items moving toward bound status lose in syntactic variability. Syntactic autonomy is a related concept that concerns the degree of syntactic integration for a given item. Obligatory items that belong to the core grammar (e.g. inflectional affixes) have a high degree of syntactic integration. The more optional an item is, the lower its degree of syntactic integration.

The two parameters relating to morphology are morphosyntactic properties and morphological compositionality. ${ }^{13}$ The former relates to definiteness (i.e. combinability with determiners), inflectional properties such as tense, case and number, and subcategorization features. When an item shifts to another word class, it mostly gains the morphosyntacitic properties of its new category, but loses the characteristics of its original word class. Morphological compositionality relates to the form of a linguistic item, that

${ }_{13}$ The notion of compositionality applies to compositional forms only, not to monomorphemic ones. 
is, the degree of formal transparency or opacity of compositional linguistic items. Constituent-internal reanalysis or univerbation may result in unanalyzable forms.

Changes at the level of phonology and phonetics apply to the phonological substance and prosodic weight of an item. As regards phonological substance, there may be loss of segments or lenition/fortition of remaining segments; for instance, loss and reduction in going to resulted in grammaticalized gonna. Prosodic weight pertains to such changes as the loss of sandhi effects (e.g. in the Swedish s-genitive, which lost the property of devoicing voiced consonants in the string it attaches to) or changes in word stress (e.g. in the noun ism, which, unlike the suffix ism, can receive main stress).

As regards semantics, the two parameters are semantic substance and semantic compositionality. Semantic substance has to do with referential meaning; as referential meanings fade, relational meanings become more salient. An increase in semantic substance (concretion, specialization) adds a new referential dimension to linguistic items, whereas a decrease in semantic substance (bleaching, generalization) results in more general, abstract meanings. Semantic compositionality relates to the extent to which the meaning of an expression can be derived or constructed from its component parts. It is about the degree of semantic transparency or opacity of compositional forms. The meaning of compounds, for instance, typically consists of a sum of two constituent parts carrying referential meaning. ${ }^{14}$ A decrease in semantic compositionality frequently correlates with loss of morphological compositionality, for example, in the development of Old English hlaf-weard 'bread guardian' to Modern English lord (both morphologically and semantically non-compositional), but this need not be the case. For instance, the Dutch noun schatje 'sweetie' can still be analyzed as a diminutive formation (schat 'treasure' + -je 'DIM') but it lost the compositional meaning of 'little treasure'.

Discourse and pragmatics relate to the communicative aspects of an expression. They pertain to the degree of speaker-perspective and speaker-

${ }^{14}$ The concept of semantic compositionality can also be invoked to refer to componential analysis of meaning, which is concerned with identifying "atomic" pieces of meaning. Under such an analysis, the concept of, for instance, bachelor can be decomposed into 'adult', 'human', 'male', 'unmarried' (see e.g. Wunderlich 2012 for discussion). In grammaticalization studies however, loss of such atomic components would amount to a decrease in semantic substance, because it entails a generalization of meaning. 
Table 2. Parameters of the clustering approach

Syntactic variability

Syntactic autonomy

Morphosyntactic properties

Morphological compositionality

Phonological substance

Prosodic weight

Semantic substance

Semantic compositionality

Subjectivity

Intersubjectivity
Degree of flexibility, number of syntactic slots

Degree of syntactic integration, cohesion, dependencies

Definiteness, inflection, subcategorization features

Discrete internal morpheme boundaries

Number of phonemes, segmental features (e.g. full vs. reduced vowels)

Stress, sandhi effects

Referential meaning

Meaning as sum of composite parts

Expression of speaker's belief or attitude

Speaker-addressee interaction

addressee interaction. Increasing subjectivity and/or intersubjectivity is indicative of change with respect to discourse/pragmatics. Instances of desubjectification or deintersubjectification are rare, but one (Pennsylvania German wotte 'to wish') will be given in Section 4 nevertheless. The parameters and their short descriptions are summarized in Table 2.

\subsection{Side effects}

Apart from the basic mechanisms of change and the changes on five linguistic levels discussed in the previous sections, a variety of other changes have been suggested as characteristic of izations as well. As we have argued above, we will distinguish between mechanisms of the change proper (reanalysis and reinterpretation), the primitive changes involved in these mechanisms, and the concomitants of these (micro-)changes. We call these concomitant changes side effects, because they are essentially the result of mechanisms and primitive changes. They are signs of ongoing change, or that a change has occurred, and may in turn be used as a diagnostic in identifying potential cases of lexicalization, grammaticalization, or pragmaticalization.

Like primitive changes, side effects are parametric, as we will explain in the next section. The following side effects are part of our analysis: 
(i) Paradigmaticization (see Lehmann 1995 [1982]): 132-137): an increase in paradigmaticity, that is, the degree to which a sign is integrated into an (inflectional) paradigm; ;5 we also use "paradigmaticization" for a transfer from open to closed category (cf. Norde 2012b: 74)

(ii) Obligatorification (see Lehmann 1995 [1982]: 137-143): a decrease in paradigmatic variability

(iii) Condensation (cf. Lehmann 1995 [1982]: 143-147): ${ }^{16}$ the reduction of structural scope

(iv) Layering ${ }^{17}$ (see Hopper 1991): synchronic gradience of a sign, that is, the co-existence of older and newer forms and/or functions; the related concepts of divergence (split), specialization, and persistence are all associated with gradience

(v) Productivity (see Brinton \& Traugott 2005: 110): type frequency, or host-class expansion as defined by Himmelmann (2004: 33)

(vi) Token frequency (see Brinton \& Traugott 2005: 110)

(vii) Typological generality (see Brinton \& Traugott 2005: 110): cross-linguistic replication

The first three changes listed above are characteristics of the category of which the "izing" item is to become a member (cf. von Mengden's 2008 criticism of Lehmann's parameter of variability). For example, when a function word develops into an affix (as in the emergence of the suffixed article of definiteness out of a demonstrative pronoun discussed in the next section), it becomes part of a paradigm as well as grammatically obligatory, by virtue of its becoming a suffix. Similarly, when an adverb develops into a

\footnotetext{
${ }_{15}$ Note that paradigmatic cohesion (paradigmaticity) is a parameter in Lehmann's model (Table 1). We do not consider it a primitive change, however (like other changes associated with Lehmann's parameters), because (de)paradigmaticization is not a change in a specific property of a given item or construction, but pertains to the (re-)organization of the grammatical system. For instance, instead of viewing each individual suffix in the Romance inflectional future paradigms as an instance of paradigmaticization, we would argue that the rise of this inflectional category as a whole is paradigmaticization, which is the epiphenomenal result of grammaticalization of various forms of auxiliary verb deriving from Latin habere 'have (to)'.

${ }^{16}$ Lehmann's parameter of "structural scope" is notoriously problematic, because it does not appear to have a clear directional preference in either grammaticalization or degrammaticalization (see Norde 2012a: 83, 102-103, for a discussion of this parameter)

${ }_{17}$ We understand layering as the synchronic co-existence of more and less grammaticalized variants of a given form. This is now the common interpretation of the term, but Hopper (1991: 23) originally coined it for "the prominent fact that very often more than one technique is available in a language to serve similar or even identical functions" (this shift in interpretation of the term was observed in Van Bogaert 2010: footnote 12).
} 
discourse marker, its scope inherently increases because discourse markers take scope over the entire proposition.

Layering and its close associates divergence, specialization, and persistence are reflections of the gradualness of izations, with older and newer forms and functions typically co-existing for an often considerable period of time. They are no primitive changes, but they are important diagnostics, because they distinguish between abrupt changes (e.g. adposition $>$ noun conversions) and the gradual changes that are izations, whereby a series of contiguous changes occurs in bridging contexts. Similarly, persistence (of former formal and semantic properties) is only attested in gradual change.

Type and token frequency are likewise considered side effects. In our view, an increase in type frequency, or context expansion, is a function of the loss of referential meaning (a primitive change on the semantic level). By this, we mean that a semantically bleached item imposes fewer restrictions on the items it can co-occur with. Context expansion is therefore seen as a reasonable consequence of bleaching, or as a subsequent stage (Szczepaniak 2011: 12)

Changes (v) and (vi), finally, will not be considered in our analyses in the present article, because we do not have sufficient data for all of the examples we will discuss in the next section. When cases are examined in more (empirical) detail, however, we feel that frequency, in particular, ought to be considered.

\section{The clustering approach: Examples of analysis}

In this section, we will apply our clustering approach to a set of well-known case studies. They will not be discussed in much detail here (but references are given), as our primary concern is to show how primitive changes cluster, and which side effects are relevant. In Table 3, we present the changes that have been analyzed, as well as the labels traditionally assigned to them. For most changes these labels are fairly uncontroversial, but others (the interface cases) have been assigned to more than one category; in such cases, both labels are given.

For each of the changes in Table 3, we examined the major mechanisms, the presence versus absence of bridging contexts, the primitive changes, and some side effects. For the primitive changes, we indicate whether they involved reduction, expansion, or neither with respect to the parameters 
Table 3. Changes to be analyzed in this section, and their traditional labels

Change
English motion verb be going to $>$
future auxiliary be gonna

future auxiliary be gonna

Proto-Scandinavian demonstrative pronoun, e.g. in *hüs (h)it 'house that' $>$ Old Norse bound definite article, e.g. húsit 'house.DEF 'the house' > Norwegian suffix of definiteness Old English hlaf weard 'loaf guardian' $>$ Modern English lord

English derivational suffix ism $>$ noun ism

English discourse marker $y^{\prime} k$ now $(<$ you know)

Mainland Scandinavian jeg tror (Danish, Norwegian), jag tror (Swedish) 'I think'

Pennsylvania German wotte modal auxiliary 'would' > main verb 'wish' (Burridge 1998)

Welsh adpostion yn ol 'after' > lexical verb nôl 'fetch' (Willis 2007)

Old English and Old Mainland Scandinavian MASCULINE/NEUTER singular genitive suffix $s>$ Modern enclitic $s$-genitive

Early Modern Irish first person plural verbal suffix maid > Connemara Irish pronoun muid 'we' (Doyle 2002)

outlined in Table 2. All our findings are summarized in Table 4. For each composite change, we provide the type of reanalysis, or the word class (major or minor) of input and output, and indicate whether or not the change occurred in a bridging context. We also indicate whether the input
Traditional label(s)

Grammaticalization (Fischer \& Rosenbach 2000), more specifically primary grammaticalization $(\mathrm{MN} \& \mathrm{~KB})$

Grammaticalization (Enger 2013), more specifically, in our view, secondary

grammaticalization

Lexicalization as fusion (Brinton \& Traugott 2005)

Lexicalization as separation (Brinton \& Traugott 2005)/degrammaticalization (Ramat 1992)

Grammaticalization (Brinton \& Traugott 2005)/pragmaticalization

(Aijmer 1997)

Hybrid (Beijering 2012)

Degrammation (Norde 2009)

Degrammation (Norde 2009)

Deinflectionalization (Norde 2009)

Debonding (Norde 2009) 
and output categories have referential or relational meaning. For the primitive changes, we specify whether they involve expansion (+), reduction $(-)$, or neither $(\varnothing)$. Side effects, finally, may be attested $(\square)$, they may not be attested $(\square)$, or their reverse may be attested $(囚) .{ }^{18}$

Even though Table 4 (overleaf) contains only a limited number of changes, some tendencies may be identified.

(i) Semantic reinterpretation largely correlates with categorical reanalysis. That is, major word classes correlate with referential meaning and minor word classes with relational meaning. The only exceptions are discourse markers: following Dostie (2009), we consider them a minor category, albeit with communicative rather than relational meaning.

(ii) Semantic substance almost always correlates with semantic reinterpretation, except of the case of the $s$-genitive, which gains in semantic substance (because the function of definiteness has been added; Norde 2009: 171), yet does not acquire referential meaning.

(iii) Most izations occur in bridging contexts, with the exception of ism, which is an instance of lexicalization as separation. For Pennsylvania German wotte '(auxiliary) would' > '(main verb) wish', which evolved from a modal construction in which the main verb was elided, there is no historical evidence (as far as we know) for a construction in which wotte was ambiguous, so we left a question mark there.

(iv) With ten parameters and three values, there are in principle 979 ways in which primitive changes may cluster, ${ }^{19}$ but the examples given here suggest that the possibilities are in fact far more limited. The general picture that arises when considering these prototypical instances of the various izations is that they relate primarily to the degree of the overall autonomy of an element within the linguistic system (see Lehmann 1995 [1982]). That is, grammatical items typically lose autonomy and substance on all linguistic levels because movement toward core grammar is accompanied by tighter integration and dependencies within the linguistic system. Lexical

\footnotetext{
${ }_{18}$ Layering and typological generality only have two values: $\square$ and $\square$.

19 That is, there are $10^{3}=1$,000 possible combinations, but the outcome where all primitive changes would be $\varnothing$, as well as the outcomes where only one primitive change would represent either reduction or expansion, have had to be excluded. In the first case, nothing changes, and in the second case, there is only a single primitive change, and hence there is no composite change. In all, then, there are $1+10+10=21$ invalid outcomes.
} 
Table 4. Clusterings of mechanisms, primitive changes and side effects in some composite changes

\begin{tabular}{cllll}
\hline & & gonna & -en/-et & lord \\
\hline MAIN MECHANISMS & & & \\
& Categorical & MAJOR $>$ & MINOR $>$ & MAJOR $>$ \\
& reanalysis & MINOR; & MINOR; & MAJOR; \\
& bridging & bridging & bridging \\
& context & context & context \\
& Semantic & REF $>$ & REL $>$ & REF $>$ \\
& reinterpretation & REL & REL & REF
\end{tabular}

PRIMITIVE CHANGES

\begin{tabular}{lllll} 
Linguistic level & Parameter & & & \\
Syntax & Syntactic variability & - & - & $\varnothing$ \\
& Syntactic autonomy & - & - & $\varnothing$ \\
Morphology & $\begin{array}{l}\text { Morphosyntactic } \\
\text { properties }\end{array}$ & - & $\varnothing$ & $\varnothing$ \\
& $\begin{array}{l}\text { Morphological } \\
\text { compositionality }\end{array}$ & - & $\varnothing$ & - \\
& Phonological & - & - & - \\
Phonology \& & substance & & & \\
phonetics & Prosodic weight & - & - & $\varnothing$ \\
Semantics & Semantic substance & - & - & $\varnothing$ \\
& $\begin{array}{l}\text { Semantic } \\
\text { compositionality }\end{array}$ & - & $\varnothing$ & - \\
Discourse \& & Subjectivity & + & + & $\varnothing$ \\
pragmatics & Intersubjectivity & $\varnothing$ & + & $\varnothing$ \\
SIDE EFFECTS & & & & \\
& Paradigmaticization & $\square$ & $\square$ & $\square$ \\
& $\begin{array}{l}\text { Obligatorification } \\
\text { Condensation }\end{array}$ & $\square$ & $\square$ & $\square$ \\
& Layering & $\square$ & $\square$ & $\square$ \\
& Typological generality & $\square$ & $\square$ & $\square$ \\
& & & & $\square$ \\
\hline
\end{tabular}




\begin{tabular}{lllllll}
\hline ism & y'know & jeg tror & wotte & nôl & s & muid \\
\hline & & & & & \\
MINOR $>$ & MAJOR $>$ & MAJOR $>$ & MINOR $>$ & MINOR $>$ & MINOR $>$ & MINOR $>$ \\
MAJOR; & MINOR; & MINOR; & MAJOR; & MAJOR; & MINOR; & MINOR; \\
no bridging & bridging & bridging & bridging & bridging & bridging & bridging \\
context & context & context & context (?) & context & context & context \\
REL $>$ & REF $>$ & REF $>$ & REL $>$ & REL $>$ & REL $>$ & REL $>$ \\
REF & COMM & COMM & REF & REF & REL & REL
\end{tabular}

\begin{tabular}{|c|c|c|c|c|c|c|}
\hline+ & + & + & + & + & $\varnothing$ & + \\
\hline+ & + & + & + & + & $\varnothing$ & + \\
\hline+ & - & - & + & + & $\varnothing$ & + \\
\hline$\varnothing$ & - & $\varnothing$ & $\varnothing$ & - & $\varnothing$ & $\varnothing$ \\
\hline$\varnothing$ & - & $\varnothing$ & $\varnothing$ & - & $\varnothing$ & $\varnothing$ \\
\hline+ & $\varnothing$ & $\varnothing$ & + & + & + & + \\
\hline+ & - & - & + & + & + & $\varnothing$ \\
\hline$\varnothing$ & - & - & $\varnothing$ & $\varnothing$ & $\varnothing$ & $\varnothing$ \\
\hline$\varnothing$ & + & + & - & + & + & $\varnothing$ \\
\hline$\varnothing$ & + & + & - & - & + & $\varnothing$ \\
\hline$\square$ & $\nabla$ & च & 凶 & 凶 & 凶 & 凶 \\
\hline$\square$ & $\square$ & $\square$ & $\square$ & $\square$ & $\square$ & $\square$ \\
\hline$\nabla$ & 凶 & 网 & 唯 & $\square$ & 凶 & 凶 \\
\hline$\nabla$ & $\nabla$ & $\nabla$ & $\square$ & $\square$ & $\nabla$ & $\square$ \\
\hline$\nabla$ & $\nabla$ & $\nabla$ & $\square$ & $\square$ & $\nabla$ & $\square$ \\
\hline
\end{tabular}


items resulting from fusion change with respect to compositionality (semantics + morphology), but there is no change of category leading to altered dependencies within the system. The autonomy of fused lexical items remains unaffected as they remain subject to the general rules of grammar and word combining. Lexical items resulting from separation are on their way of becoming autonomous words. Discourse markers, on the other hand, are not subject to the rules of grammar but operate at the level of discourse. They witness an increase in autonomy, in the sense that they become syntactically independent units, which function as additional comments toward the proposition.

(v) On the whole, reduction is more common on all levels, with the exception of discourse. This overall tendency toward reduction is rooted in usage, and the observation that frequency correlates with semantic and phonological attrition. Or, as Langacker (1977: 106-107) put it: "[L]anguages in their diachronic aspect are gigantic expression-compacting machines". (For the general tendency toward reduction, see Norde 2009: 90-93).

(vi) The opposite direction in change on the level of discourse is consistent with Traugott's (2010) idea of grammaticalization as expansion, which she construes as pragmatic enrichment and an increase in discourse prominence. It is also consistent with Norde's (2012a) claim that subjectification is far more common than desubjectification, because it is even attested in some instances of degrammaticalization.

(vii) At some levels, expansion is extremely rare. Phonological strengthening is not attested in the case studies in this article (but note that in almost half of the cases there is no phonological change at all). ${ }^{20}$ A shift from a non-compositional item (both in terms of morphology and semantics) is, as far as we know, only attested in folk etymology, for example, when Spanish hamaca 'hammock' was reinterpreted as Dutch hang-mat, a mat one can hang in.

${ }^{20}$ One of the few examples of phonological strengthening is found in the development of Dutch tig 'dozens', which derives from the suffix tig as in vijftig 'fifty'. In the suffix, the vowel is [ə], but in the indefinite quantifier, which is always stressed, the vowel is [1] (Norde 2009: 213-220). 
(viii) As to side effects, ${ }^{21}$ it can be noted that paradigmaticization occurs both in grammaticalization and pragmaticalization, whereas the reverse (deparadigmaticization) occurs in all examples of degrammaticalization in this table. Obligatorification is restricted to (both primary and secondary) grammaticalization. Condensation (scope change) does not seem to have a directional preference (see fn. 10). Layering is very commonly attested; except, for instance, when the change happened a very long time ago and the original construction is no longer present (as in the case of the suffixed article in Norwegian; the demonstrative pronoun from which it evolved has now disappeared from the language). Typological generality is characteristic of both grammaticalization and pragmaticalization, whereas the lexicalization and degrammaticalization changes in this table are restricted to a single language (or a few related languages at best, as in the case of the $s$-genitive, which is attested in both English and Continental Scandinavian).

Looking at some of the composite changes in more detail, we may note subtle differences between changes that have been categorized as the same ization. For example, English $y^{\prime} k n o w$ and Danish jeg tror 'I guess' are originally both mental state predicates, but $y^{\prime}$ know is further advanced toward discourse marker status, as it has decreased in phonological substance and morpheme boundaries have disappeared. The latter is not true for jeg tror, because in constructions requiring $\mathrm{V} 2,^{22}$ the verb and the pronoun are reversed, as in the following example from Danish (Beijering 2012: 187):

(20) Desvoerre gjorde det ikke indtryk på Agathe, snarere tvertimod tror jeg. 'Unfortunately it did not impress Agathe, rather the opposite I guess.'

It can be observed that the syntactic autonomy and variability of $y^{\prime} k n o w$ as well as jeg tror increase because they become syntactically independent units. Their semantic compositionality is affected as well because their predominant meaning is no longer their original literal meaning (i.e. the cognitive act). That is, the meaning of $y^{\prime} k$ now and jeg tror cannot be straightforwardly derived from their component parts. As regards

\footnotetext{
${ }^{21}$ We did not include the side effects of productivity and token frequency in the table, because information was not available for all changes.

${ }_{22}$ The Mainland Scandinavian languages are V2-languages, i.e. the finite verb obligatorily occurs in the second slot in main clauses.
} 
semantic substance, there is weakening of the original cognitive meaning, whereas communicative meanings become more prominent.

Another instance of changes bearing the same label but differing nevertheless are the two cases of degrammation: Welsh yn ol 'after' > nôl 'fetch' and Pennsylvania German wotte 'would' > 'wish'. As we have seen in example (18a), the change in Welsh yn ol occurred in a bridging context, but for wotte this is not certain (see (iii) above). Another difference is that yn ol became univerbated and reduced, whereas wotte underwent neither of these changes. Finally, they also differ at the level of discourse. The shift from $y n$ ol to nôl involved pragmatic enrichment and subjectification - for if somebody is going after something, the speaker invites the interpretation that s/he does so with the intention to fetch it. In the case of wotte, however, the reverse appears to have occurred. For this particular example, it is relevant to keep in mind that the speakers of Pennsylvania German are a deeply religious people who want to avoid the blunt expression of wishing (Burridge 1998: 32). In using a modal form, they dissociate the act of wishing from themselves, placing the occurrence of what they wish for entirely in the hands of God. Paradoxically then, the modal is not used to express the speaker's evaluation of the likelihood of an event taking place (which is what epistemic modals usually do), but to avoid such an evaluation altogether. This makes Pennsylvania wotte a case of desubjectification, as the speaker does not express his own will but distances himself from the proposition (see also Norde 2012b: 53).

\section{Conclusions and outlook}

In this article, we have critically reviewed current theories on grammaticalization. We acknowledge that the grammaticalization framework provides valuable diagnostics to identify tendencies in language change, but there is one major problem, which is that the izations do not form a Linnaean taxonomy. In this article, we aimed to show that lexicalization, grammaticalization, and pragmaticalization have much in common, but that there are also fundamental differences that are due to the different functional domains to which they apply. The essence of lexicalization, grammaticalization, and pragmaticalization is defined in terms of formal reanalysis and semantic reinterpretation within or between different domains of language 
(i.e. lexicon, grammar, discourse). In addition, lexicalization, grammaticalization, and pragmaticalization are conceived of as composite changes that are made up of basic mechanisms of change, a subset of correlated primitive changes at different linguistic levels (phonology/phonetics, morphology, syntax, semantics, and discourse/pragmatics), and the concomitants of these (micro-)changes. Our analysis shows that pragmaticalization is genuinely different from lexicalization and grammaticalization, and should therefore be defined in its own right.

By introducing the clustering approach, we hope to have provided the framework of grammaticalization studies with more explicit tools of analysis. Our criteria for classification (in terms of main mechanisms, primitive changes, and side effects) will likely give less rise to confusion than using the (sometimes implicit) definitions of the izations themselves as a basis for classification. We expect that our approach, once a substantial data set has been analyzed, will be able to identify both prototypical and marginal instances of a particular type of change. Moreover, a clustering approach is able to deal with the gradient nature (i.e. emerging categories) of lexicalization, grammaticalization, and pragmaticalization, and captures borderline cases and interface areas.

Obviously, this article has only dealt with a limited number of izations. In future work, we aim to test our approach against a far more substantial dataset, which should enable us to gain a better understanding how mechanisms, primitive changes, and side effects cluster, as well as explaining just why they cluster in these ways, and why other clusters are never attested at all. In order to do so, we are working on an interactive database and website $^{23}$ to collect as many attested cases of language change as possible. These data will enable us to draw generalizations on the basis of a large sample of empirical data, and make statistical rather than absolute claims on prototypical properties and clusters of primitive changes, found in grammaticalization and related izations.

Note, finally, that in this article we intended to outline a cluster-based model of analysis, without discussing the underlying motivations for the main mechanisms and primitive changes involved in izations, for instance as the result of cognitive mechanisms or speaker-hearer interactions. This, too, we consider an important theoretical issue for further study.

\footnotetext{
${ }^{23}$ See www.clustersofchange.com (under construction). Launch expected in 2015.
} 


\section{List of abbreviations}

$\begin{array}{llll}1 & \text { first person } & \text { IMP } & \text { imperative } \\ 3 & \text { third person } & \text { INF } & \text { infinitive } \\ \text { DAT } & \text { dative } & \text { MASC } & \text { masculine } \\ \text { DEF } & \text { definite } & \text { PART } & \text { particle } \\ \text { DIM } & \text { diminutive } & \text { PL } & \text { plural } \\ \text { FUT } & \text { future } & \text { SG } & \text { singular }\end{array}$

\section{References}

Abraham, Werner. 1991. The grammaticization of the German modal particles. In Elizabeth Closs Traugott \& Bernd Heine, eds. Approaches to grammaticalization, vol. II. Amsterdam: John Benjamins, 331-380.

Adger, David. 2003. Core syntax: A minimalist approach. Oxford: Oxford University Press.

Aijmer, Karin. 1997. I think - An English modal particle. In Toril Swan Toril \& Olaf Jansen Westvik, eds. Modality in Germanic languages. Historical and comparative perspectives. Berlin: Mouton de Gruyter, 1-47.

Aijmer, Karin \& Anne-Marie Simon-Vandenbergen. 2009. Pragmatic markers. In Jan-Ola Östman \& Jef Verschueren, eds. Handbook of pragmatics. Amsterdam: John Benjamins, 1-29

Askedal, John Ole. 2003. Grammaticalization and the historical development of the genitive in Mainland Scandinavian. In Barry J. Blake \& Kate Burridge, eds. Papers from the 15th International Conference on Historical Linguistics. Amsterdam: John Benjamins, 21-32.

Beijering, Karin. 2012. Expressions of epistemic modality in Mainland Scandinavian: A study into the lexicalization-grammaticalization-pragmaticalization interface. Groningen: University of Groningen PhD dissertation.

Blank, Andreas. 2001. Pathways of lexicalization. In Martin Haspelmath, Ekkehard König, Wulf Oesterreicher \& Wolfgang Raible, eds. Language typology and language universals, vol. II. Berlin: Mouton de Gruyter, 1596-1608.

Boye, Kasper \& Peter Harder. 2012. A usage-based theory of grammatical status and grammaticalization. Language 88: 1-44.

Brinton, Laurel J. 1996. Pragmatic markers in English: Grammaticalization and discourse functions. Berlin: Mouton de Gruyter.

Brinton, Laurel J. \& Elizabeth Closs Traugott. 2005. Lexicalization and language change. Cambridge: Cambridge University Press.

Burridge, Kate. 1998. From modal auxiliary to lexical verb: The curious case of 
Pennsylvania German wotte. In Richard M. Hogg \& Linda van Bergen, eds. Historical linguistics 1995. Vol. 2: Germanic linguistics. Amsterdam: John Benjamins, 19-33.

De Smet, Hendrik. 2009. Analysing reanalysis. Lingua 119: 1728-1755.

Detges, Ulrich \& Richard Waltereit. 2002. Grammaticalization vs. reanalysis: A semantic-pragmatic account of functional change in grammar. Zeitschrift für Sprachwissenschaft 21: 151-195.

Diewald, Gabriele. 2011. Pragmaticalization (defined) as grammaticalization of discourse functions. Linguistics 49:365-390.

Dostie, Gaétane. 2009. Discourse markers and regional variation in French: A lexico-semantic approach. In Kate Beeching, Nigel Armstrong \& Françoise Gadet, eds. Sociolinguistic variation in contemporary French. Amsterdam: John Benjamins, 201-214.

Doyle, Aidan. 2002. Yesterday's affixes as today's clitics: A case-study in degrammaticalization. In Ilse Wischer \& Gabriele Diewald, eds. New reflections on grammaticalization. Amsterdam: John Benjamins, 67-81.

Enger, Hans-Olav. 2013. Morphological theory and grammaticalisation: The role of meaning and local generalisations. Language Sciences 36: 18-31.

Fischer, Olga. 2007. The development of English parentheticals: A case of grammaticalization? In Ute Smit, Stefan Dollinger, Julia Hüttner, Gunther Kaltenböck \& Ursula Lutzky, eds. Tracing English through time. Vienna: Braumüller, 99-114.

Fischer, Olga. 2008. On analogy as the motivation for grammaticalization. Studies in language 32: $336-382$.

Fischer, Olga \& Annette Rosenbach. 200o. Introduction. In Olga Fischer, Annette Rosenbach \& Dieter Stein, eds. Pathways of change: Grammaticalization in English. Amsterdam: John Benjamins, 1-37.

Foucault, Michel. 1972. Histoire de la folie à l'âge classique. Paris: Gallimard.

Gould, Stephen J. \& Elizabeth S. Vrba. 1982. Exaptation: A missing term in the science of form. Paleobiology 8: 4-15.

Gutting, Gary. 2005. Foucault and the history of madness. In Gary Gutting, ed. The Cambridge companion to Foucault. Cambridge: Cambridge University Press, 49-73.

Haspelmath, Martin. 1998. Does grammaticalization need reanalysis? Studies in language 22: 315-351.

Haspelmath, Martin. 1999. Why is grammaticalization irreversible? Linguistics 37: 1043-1068.

Heine, Bernd. 2002. On the role of context in grammaticalization. In Ilse Wischer \& Gabriele Diewald, eds. New reflections on grammaticalization. Amsterdam: John Benjamins, 83-101.

Heine, Bernd. 2013. On discourse markers: Grammaticalization, pragmaticalization, or something else? Linguistics 51: 1205-1247. 
Heine, Bernd \& Mechtild Reh. 1984. Grammaticalization and reanalysis in African languages. Hamburg: Buske Verlag.

Himmelmann, Nikolaus P. 2004. Lexicalization and grammaticalization: Opposite or orthogonal? In Walter Bisang, Nikolaus P. Himmelmann \& Björn Wiemer, eds. What makes grammaticalization? A look from its fringes and its components. Berlin: Mouton de Gruyter, 21-42.

Hopper, Paul J. 1991. On some principles of grammaticization. In Elizabeth C. Traugott \& Bernd Heine, eds. Approaches to grammaticalization, vol. I. Amsterdam: John Benjamins, 17-35.

Hopper, Paul J. \& Elizabeth Closs Traugott. 2003 [1993]. Grammaticalization. 2nd edn. Cambridge: Cambridge University Press.

Kuryłowicz, Jerzy. 1975 [1965]. The evolution of grammatical categories. Esquisses linguistiques 2: 38-54.

Langacker, Ronald W. 1977. Syntactic reanalysis. In Charles N. Li, ed. Mechanisms of syntactic change. Austin: University of Texas Press, 57-139

Lass, Roger. 1990. How to do things with junk: Exaptation in language evolution. Journal of Linguistics 26: 79-102.

Lehmann, Christian. 1995 [1982]. Thoughts on grammaticalization. Munich: Lincom Europa.

Lehmann, Christian. 2004. Theory and method in grammaticalization. Zeitschrift für Germanistische Linguistik 32: 152-187.

Lewis, Diana. 2011. A discourse-constructional approach to the emergence of discourse markers in English. Linguistics 49 : 415-443.

Meillet, Antoine. 1958 [1912]. L'évolution des formes grammaticales. In Antoine Meillet, ed. Linguistique historique et linguistique générale. Paris: Edouard Champion, 130-148. (First published in Scientia (Rivista di scienzia) 12: 384400 .

Narrog, Heiko \& Bernd Heine. 2011. Introduction. In Heiko Narrog \& Bernd Heine, eds. The Oxford handbook of grammaticalization. Oxford: Oxford University Press, 1-16.

Newmeyer, Frederick J. 1998. Language form and language function. Cambridge, MA: MIT Press.

Norde, Muriel. 1997. The history of the genitive in Swedish: A case study in degrammaticalization. Amsterdam: University of Amsterdam PhD dissertation.

Norde, Muriel. 2009. Degrammaticalization. Oxford: Oxford University Press.

Norde, Muriel. 2011. Degrammaticalization. In Heiko Narrog \& Bernd Heine, eds. The Oxford handbook of grammaticalization. Oxford: Oxford University Press, $475-487$.

Norde, Muriel. 2012a. Lehmann's parameters revisited. In Kristin Davidse, Tine Breban, Lot Brems \& Tanja Mortelmans, eds. Grammaticalization and language change: New reflections. Amsterdam: John Benjamins, 73-110. 
Norde, Muriel. 2012b. (De)grammaticalization and (de)subjectification. In Johan van der Auwera \& Jan Nuyts, eds. Grammaticalization and (inter-)subjectification. Royal Flemish Academy of Belgium for Sciences and the Arts: Contactforum, 37-63.

Ocampo, Francisco. 2006. Movement towards discourse is not grammaticalization: The evolution of claro from adjective to discourse particle in spoken Spanish. In Nuria Sagarra \& Almeida Jacqueline Toribio, eds. Selected proceedings of the 9th Hispanic Linguistics Symposium. Somerville, MA: Cascadilla Proceedings Project, 308-319.

Onodera, Noriko. 2011. The grammaticalization of discourse markers. In Heiko Narrog \& Bernd Heine, eds. The Oxford handbook of grammaticalization. Oxford: Oxford University Press, 614-624.

Ramat, Paolo. 1992. Thoughts on degrammaticalization. Linguistics 30: 549-560.

Rosenkvist, Henrik. 2004. The emergence of conditional subordinators in Swedish: A Study in grammaticalization. Lundastudier i nordisk språkvetenskap A62. Lund: Department of Scandinavian Languages.

Schiffrin, Deborah. 1987. Discourse markers. Cambridge: Cambridge University Press.

Szczepaniak, Renata. 2011 [2009]. Grammatikalisierung im Deutschen: Eine Einführung. Tübingen: Narr Verlag.

Thompson, Sandra A. \& Anthony Mulac. 1991. A quantitative perspective on the grammaticalization of epistemic parentheticals in English. In Elizabeth Closs Traugott \& Bernd Heine, eds. Approaches to grammaticalization, vol. II. Amsterdam: John Benjamins, 313-329.

Traugott, Elizabeth Closs. 1997. The role of the development of discourse markers in a theory of grammaticalization. Paper presented at ICHL XII, Manchester 1995. http://www.stanford.edu/ traugott/papers/discourse.pdf. Last accessed 16 Oct. 2014.

Traugott, Elizabeth Closs. 2002. From etymology to historical pragmatics. In Donka Minkova \& Robert Stockwell, eds. Studies in the history of the English language. Berlin: Mouton de Gruyter, 19-49.

Traugott, Elizabeth Closs. 2010. Grammaticalization. In Silvia Luraghi \& Vit Bubenik, eds. A companion to historical linguistics. London: Continuum Press, 269-283.

Traugott, Elizabeth Closs \& Richard B. Dasher. 2001. Regularity in semantic change. Cambridge: Cambridge University Press.

Trousdale, Graeme \& Muriel Norde. 2013. Degrammaticalization and constructionalization: Two case studies. Language Sciences 36: 32-46.

Van Bogaert, Julie. 2010. A constructional taxonomy of $I$ think and related expressions: Accounting for the variability of complement-taking mental predicates. English Language and Linguistics 14: 399-427. 
von Mengden, Ferdinand. 2008. The modules of grammatical change. Paper presented at New reflections on grammaticalization 4, University of Leuven, 16-19 July 2008.

Willis, David. 2007. Syntactic lexicalization as a new type of degrammaticalization. Linguistics 45: 271-310.

Wischer, Ilse. 2000. Grammaticalization versus lexicalization: "methinks" there is some confusion. In Olga Fischer, Anette Rosenbach \& Dieter Stein, eds. Pathways of change: Grammaticalization in English. Amsterdam: John Benjamins, 355-370.

Wunderlich, Dieter. 2012. Lexical decomposition in grammar. In Wolfram Hinzen, Edouard Machery \& Markus Weming, eds. The Oxford handbook of compositionality. Oxford: Oxford University Press, 307-327.

Authors' addresses:

Muriel Norde

Department of Northern European Studies

Submitted: 28 January 2013

Humboldt University of Berlin

Revision invited: 30 August 2013

Unter den Linden 6

Revision received: 9 November 2013

D-10099 Berlin

Accepted: 17 February 2014

Germany

muriel.norde@hu-berlin.de

Karin Beijering

Center for Grammar, Cognition and Typology

University of Antwerp - CST

Department of Linguistics

Prinsstraat 13, R112

B-200o Antwerp

Belgium

karin.beijering@uantwerpen.be 